\title{
Analisis Standar Minimal Pergudangan Pada Logistik Pemilihan Umum Serentak Di Indonesia
}

\author{
Resista Vikaliana, I Nyoman Purnaya \\ Manajemen Logistik, Fakultas Ilmu Sosial dan Manajemen, Institut Ilmu Sosial Dan Manajemen Stiami \\ Email korespondensi: resistav31@gmail.com
}

\begin{abstract}
Abstrak
Tujuan Penelitian ini adalah untuk mengetahui standar minimal pergudangan logistik pemilu di daerah perkotaan. Penelitian ini bermanfaat dalam memberikan masukan pada Pemilu yang untuk pertama kali dilakukan serentak ini. Masukan tersebut diharapkan dapat meningkatkan efektifitas dalam penyaluran atau distribusi surat suara sehingga dapat menghasilkan surat suara dan perangkat lainnya yang yang baik, pada saat diperlukan oleh pihak-pihak yang terkait. Penelitian ini menggunakan pendekatan kualitatif dengan wawancara mendalam dengan key informan, observasi dan studi dokumentasi. Berdasarkan hasil penelitian, maka disimpulkan KPUD Kota Depok sudah memenuhi kriteria gudang yang baik sebagai gudang logistik pemilu, karena sudah memenuhi kriteria standar minimal gudang yang baik, Sehingga disarankan KPUD menggunakan kriteria gudang tersebut, untuk menjamin kualitas dan keamanan logistik pemilu.
\end{abstract}

Kata kunci: logistik pemilu, pemilu serentak, standar gudang,

\section{PENDAHULUAN}

Pemilihan Umum merupakan amanat Pembukaan Undang-Undang Dasar Negara Republik Indonesia tahun 1945. Sesuai dengan amanat tersebut, UU no 7 tahun 2017 tentang pemilihan umum mengatur pemilihan umum sebagai perwujudan sistem ketatanegaraan yang demokratis dan berintegritas demi menjamin konsistensi dan kepastian hukum serta pemilihan umum yang efektif dan efisien. (Rahadian, Vikaliana, \& Saputra, 2019)

Partisipasi dalam pemilihan umum adalah salah satu bentuk partisipasi politik dan merupakan partisipasi paling dasar dalam demokrasi. Partisipasi politik adalah tindakan sukarela; warga negara biasa biasanya melakukannya untuk 
mempengaruhi keputusan publik .

Partisipasi adalah tindakan, alih-alih keinginan, niat, minat atau kemauan.

Partisipasi dalam pemilihan umum dan pemilihan presiden dengan memilih partai atau kandidat adalah salah satu bentuk partisipasi politik, termasuk dalam pemilihan presiden. (Fuad, 2014).

Selain etika penyelengaraaan pemilu yang harus dijaga (Lestari, 2015), penyelenggaraan pemilu perlu didukung manajemen logistik yang baik. Logistik pemilu, seperti tertulis dalam banyak literatur kepemiluan adalah alat untuk mengkonversi suara menjadi kursi. Logistik pemilu di banyak negara disebut juga sebagai election material. Berbeda dengan proses distribusi logistik pelaksanaan kegiatan nasional lainnya, logistik pemilu adalah sarana penting dalam perhelatan besar demokrasi yang melibatkan banyak orang dan banyak jalur. Tiga proses pasokan logistik utama yang berlangsung dalam pemilu atau pilkada saat ini adalah proses pengadaan, distribusi, dan penarikan logistik. Tidak bisa tidak, ketiga elemen tersebut adalah kunci utama kesuksesan penyelenggaraan pemilu yang genuine dan berintegritas. (Barkati, 2014).

Logistik pemilu yang baik meminimalisir surat suara yang rusak, sehingga tidak sampai mengulang produksi surat suara. Surat suara yang diterima di KPU Daerah, melalui proses sortir, pengecekan, dan pelipatan. Setelah itu, akan disimpan di gudang KPU daerah sebelum nantinya disalurkan ke tempat pemungutan suara (TPS) minimal sepekan sebelum pencoblosan/ Pemilu berlangsung. Setiap logistik yang tiba di TPS harus dalam keadaan tersegel. Di sinilah peranan gudang sangat penting. Ketepatan penerimaan suatu produk merupakan salah satu hal yang sangat penting bagi perusahaan untuk menghadapi persaingan dalam dunia industri. Begitu pula yang harus dilakukan oleh Komisi Pemilihan Umum (KPU). Gudang atau storage merupakan tempat menyimpan barang, baik bahan baku yang akan dilakukan proses manufacturing maupun barang jadi yang siap untuk dipasarkan (Purnomo, 2004). Pengaturan tata letak gudang yang baik akan mempengaruhi kelancaran operasi pergudangan dan aktivitas-aktivitas penting lainnya dalam perusahaan, diantaranya adalah proses pemindahan barang yang biasa disebut dengan material handling. Keragaman produk yang disimpan dalam gudang mempunyai pengaruh langsung pada tata letak yang optimal. 
Pada proses logistik pemilu, khususnya Pemilu Serentak, meliputi surat suara, kotak pemungutan suara, dan kelengkapan lainnya, termasuk proses pengepakan logistik dan pendukung lainnya dilaksanakan di tingkat KPU Kabupaten/ Kota, peran gudang sebagai tempat penyimpanan sebelum hingga pasca pemilu Faktor-faktor yang harus dipertimbangkan dalam layout gudang adalah nilai investasi, bongkar muat barang, fleksibilitas, lingkungan kerja, dan keselamatan atau keutuhan barang yang disimpan. Gudang juga merupakan sarana yang didesain secara khusus untuk dapat menunjang pencapaian tujuan pelayanan barang dengan biaya dan waktu seminimal mungkin.

Tujuan Penelitian ini adalah untuk mengetahui standar minimal kriteria gudang untuk Pemilu Serentak. Penelitian ini diharapkan dapat memberikan masukan terhadap standar minimal kriteria gudang pada Pemilu yang untuk pertama kali dilakukan serentak ini. Masukan tersebut diharapkan dapat meningkatkan efektifitas dalam penyimpanan atau penggunaan gudang pada Pemilu, sehingga dapat menghasilkan surat suara yang yang baik pada saat diperlukan oleh pihak-pihak yang terkait.

\section{Pemilu Serentak}

Penyelenggaraan pemilu selama ini, di mana penyelenggaraan pemilu untuk memilih anggota DPR, DPD dan DPRD yang terpisah dengan pemilu, berdampak pada besarnya beban KPU Pusat sementara KPU di daerah hanya menjadi pelaksana teknis saja. Sedangkan jika pemilu diselenggarakan serentak, namun terpisah antara nasional dan lokal, maka beban menjadi relatif lebih tertata dan merata. Untuk Pemilu Nasional Serentak, beban KPU Pusat hanya mengurusi surat suara pada level nasional. Sementara untuk Pemilu Lokal Serentak, KPU di tingkat provinsi menjadi penanggung jawab pengadaan surat suara di wilayahnya. Dengan model seperti ini, kemungkinan surat suara tertukar sangat minim karena pada Pemilu Nasional Serentak, KPU RI hanya akan mengirimkan surat suara ke 77 Dapil untuk surat suara calon anggota DPR dan ke 34 provinsi. Sementara untuk penyelenggaraan Pemilu Lokal Serentak, KPU provinsi hanya bertanggung jawab untuk melakukan pengadaan surat suara dan distribusi logistik pemilu untuk provinsinya.

Dari sisi pengaturan waktu, persiapan pemilu yang dimulai sejak dua tahun sebelum penyelenggaraan pemilu nasional serentak akan membuat persiapan 
pemilu lebih leluasa dan program-program sosialisasi dapat dilaksanakan lebih baik. Untuk penyelenggaraan pemilu lokal serentak yang dilaksanakan dua setengah tahun setelah pemilu nasional serentak juga akan memberi waktu yang cukup bagi penyelenggara untuk menyiapkannya.

\section{Logistik Pemilu}

Logistik adalah perlengkapan pemungutan suara dan dukungan perlengkapan lainnya. Proses pengepakan logistik dan pendukung lainnya seperti sortir dan lipat surat suara yang dilaksanakan di tingkat KPU Kabupaten/ Kota harus mempedomani SOP yang ditetapkan sekretaris jendral KPU dengan memperhatikan kondisi wilayah yang bersangkutan, agar lebih efektik dan efisien dalam pelaksanaannya.

Guna mendukung kelancaran sistem penyaluran kotak suara dan surat suara, maka perlu dibuat suatu sistem yang dapat memberikan layanan dan kemudahan bagi proses penyaluran kotak suara dan surat suara. Hal ini penting sekali mengingat setiap proses kegiatan yang dilakukan nantinya harus dilaporkan dalam pelaksanaannya. Laporan tersebut sangat dibutuhkan oleh pihak KPU provinsi sebagai bahan masukan dalam mengambil keputusan. Menurut Triyanto, tujuan pelaksanaan sistem penyaluran kotak suara dan surat suara tersebut adalah:

a) Memberikan layanan guna mempermudah dan memperlancar proses pelaksanaan pemilu.

b) Membantu kelancaran prosedur penyaluran kotak suara dan surat suara sehingga menjadi lebih efektif.

c) Sebagai alat bantu bagi pihak yang terlibat dalam mengawasi pelaksanaan pemilu. (Atma \& Pangkalpinang, 1998)

\section{Persediaan}

Persediaan adalah bahan-bahan, bagian yang disediakan, dan bahan-bahan dalam proses yang terdapat dalam perusahaan untuk proses produksi, serta barang-barang jadi atau produk yang disediakan untuk memenuhi permintaan dari konsumen atau pelanggan setiap waktu. Setiap perusahaan, apakah perusahaan itu perusahaan jasa ataupun perusahaan manufaktur, selalu memerlukan persediaan. Persediaan barang dagang merupakan elemen aktiva yang sangat aktif dalam operasi perusahaanperusahaan dagang, karena pembelian dan penjualan barang dagangan merupakan aktivitas atau transaksi yang paling sering terjadi. (Rangkuti, 2007). 
Persediaan barang dagangan pada umumnya dinilai pada harga terendah antara harga perolehan dan harga pasar atau nilai yang diharapkan,. Selanjutnya persediaan adalah suatu aktiva yang meliputi barang-barang milik perusahaan dengan maksud untuk dijual dalam suatu periode usaha yang normal, atau persediaan barangbarang yang masih dalam pengerjaan atau proses produksi ataupun persediaan bahan (Assauri, 1993). Menyimpan persediaan yang banyak juga memiliki kerugian, yaitu terlalu besarnya investasi pada persediaan, kemudian meningkatnya kemungkinan barang-barang yang rusak. Perlunya pengendalian persediaan yang baik dan efisien sangatlah penting untuk mengurangi dampak buruk dari hal tersebut.Pokok penting bagi manajemen dalam mengembangkan kebijakan persediaan adalah dapat meminimumkan total biaya yang berhubungan dengan proses produksi dari suatu perusahaan. Dua dasar keputusan persediaan yang harus dilakukan yaitu: banyaknya pesanan dalam satu waktu, dan banyaknya pesanan saat ini.

\section{Gudang}

Menurut Yunarto dan Santika dalam Azwir (2017) terdapat beberapa tipe gudang seperti: retail warehouse, central warehouse, manufacturing warehouse, dan distribution warehouse. Gudang memiliki fungsi sebagai tempat untuk menyimpan barang mentah, barang setengah jadi, dan barang yang siap untuk dipasarkan ataupun alat pekerja.

Sedangkan manajemen pergudangan merupakan pengontrolan atau pengawasan kegiatan pergudangan yang diharapkan dapat mengurangi pengeluaran pembelian spare part atau keperluan gudang. Dalam manajemen pergudangan terdapat beberapa aktivitas yang terdiri atas kegiatan: administrasi, penerimaan barang, penyimpanan barang, pengepakkan barang ke tempat yang dituju, dan pengeluaran barang. Keuntungan yang didapatkan dengan adanya pelaksanaan manajemen pergudangan yaitu: terhindar dari pengeluaran biaya yang tidak penting serta mengantisipasi terjadinya manipulasi data dan kesalahan dalam input data khususnya human error. (Azwir \& Patriani, 2017)

Kriteria Gudang Industri

1. Lantai:

a. Terbuat dari beton padat dengan hardener, bersifat menahan debu dan tidak tahan terhadap tumpahan larutan bahan kimia. 
b. Terbuat dari beton dilapisi ubin keramik berwarna putih dengan kriteria harus tahan terhadap bahan kimia dan goresan, mudah diperbaiki, memerlukan penutupan celah, keras dan tangguh, licin bila basah.

2. Pencahayaan: 200 Lux (satuan kekuatan cahaya) (BPOM, 2009).

3. Kebersihan

4. Kelembaban (kelembaban relatif tidak lebih dari 60\%).

5. Suhu harus berada dalam batasan yang diterima (8-250C).

6. Bahan dan material yang disimpan tidak boleh bersentuhan langsung dengan lantai. Jarak antar bahan mempermudah pembersihan dan inspeksi.

\section{METODE}

Penelitian ini menggunakan pendekatan kualitatif dengan wawancara mendalam dengan key informan, observasi dan studi dokumentasi. Penelitian ini hanya memfokuskan pada Pemilu Serentak 2019, tidak melingkupi pemilu -pemilu sebelumnya. Key informan dari penelitian ini adalah 2 Petugas KPUD dan 2 . petugas gudang pada masing-masing KPUD yakni KPUD Kota Depok dan KPUD Kota Bogor

\section{HASIL}

Penelitian dilakukan di 2 KPUD, Kota Depok dan Kota Bogor. Pemilu Serentak berdampak logis dari meningkatnya jumlah logistik pemilu, sehingga diperlukan tempat penyimpanan dengan kapasitas yang lebih besar. Pada 2 kota tersebut, masing-masing memiliki keputusan penyimpanan logistik yang berbeda.

KPUD Kota Depok beruntung dapat memperoleh sebuah gudang di kawasan pergudangan lama, yang lokasinya tidak jauh dari pusat Kota Depok. Tipe gudang pada KPUD Kota Depok ini merupakan gudang tipe distribution warehouse.

Sedangkan KPUD Kota Bogor belum menggunakan gudang seperti standar industri. Di Kota Bogor, tidak ditemukan penyewaan gudang di tengah kota atau di lokasi strategis. Sehingga, KPUD Kota Bogor meminjam satu lantai sebuah gedung pemerintah daerah.

Berdasarkan hasil penelitian, berikut ini merupakan gambar lay out gudang logistik pemilu pada Pemilu Serentak 2019 


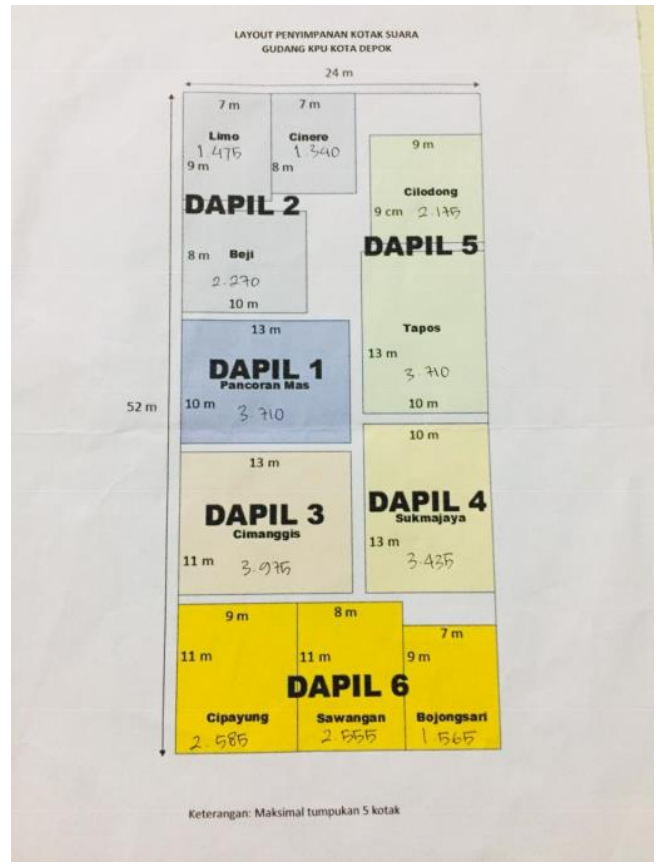

Gambar 1. Lay Out Gudang Logistik Pemilu Serentak 2019

Lay out gudang ini adalah lay out gudang di KPUD Kota Depok. Gudang di KPUD Kota Depok, meurpakan gudang standar industry yang disewa oleh KPUD Kota Depok. Gudang ini berada di sebuah kawasan pergudangan.

Pembagian area gudang pemilu di KPUD Depok
1. Area penerimaan dan pengiriman

2. Area sortir

3. Area barang logistik pemilu yang reject (rusak)

4. Area penyimpanan produk

Berikut gambar area penerimaan dan pengiriman 

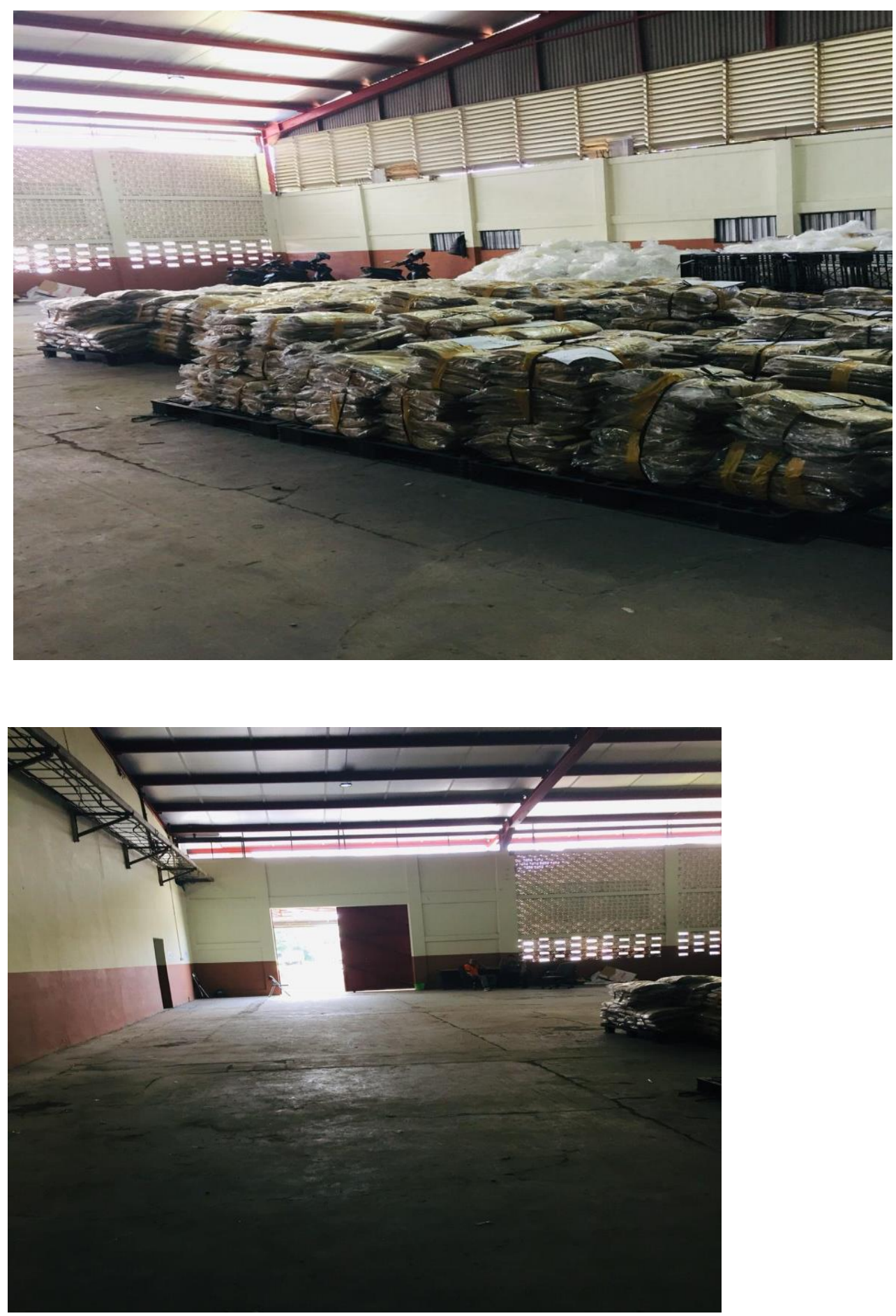

Di gudang KPUD Kota Depok ini, pintu masuk dan keluar terpusat pada satu pintu 
Berikut gambar area sortir
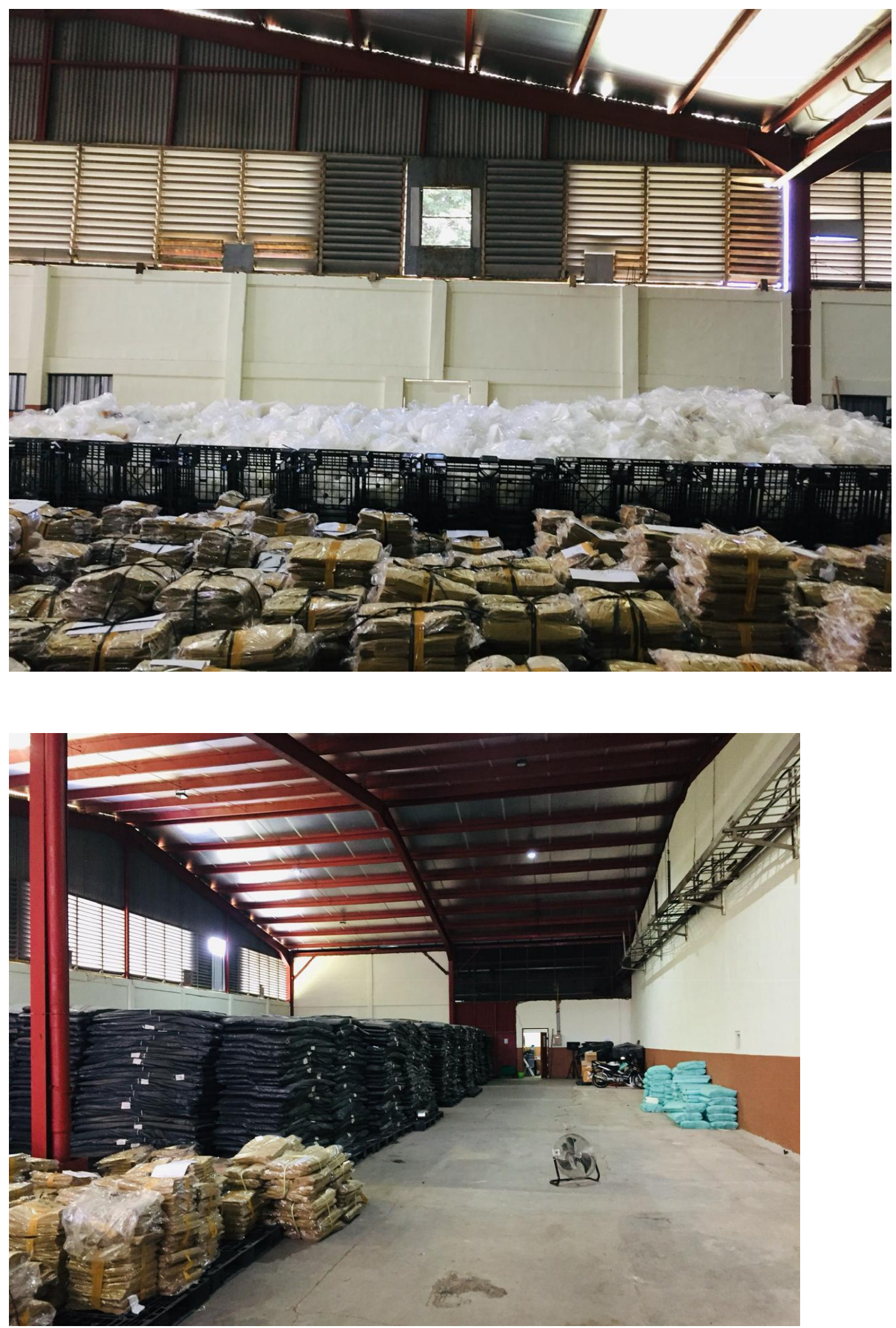
Berikut gambar area barang logistik pemilu yang reject (rusak)

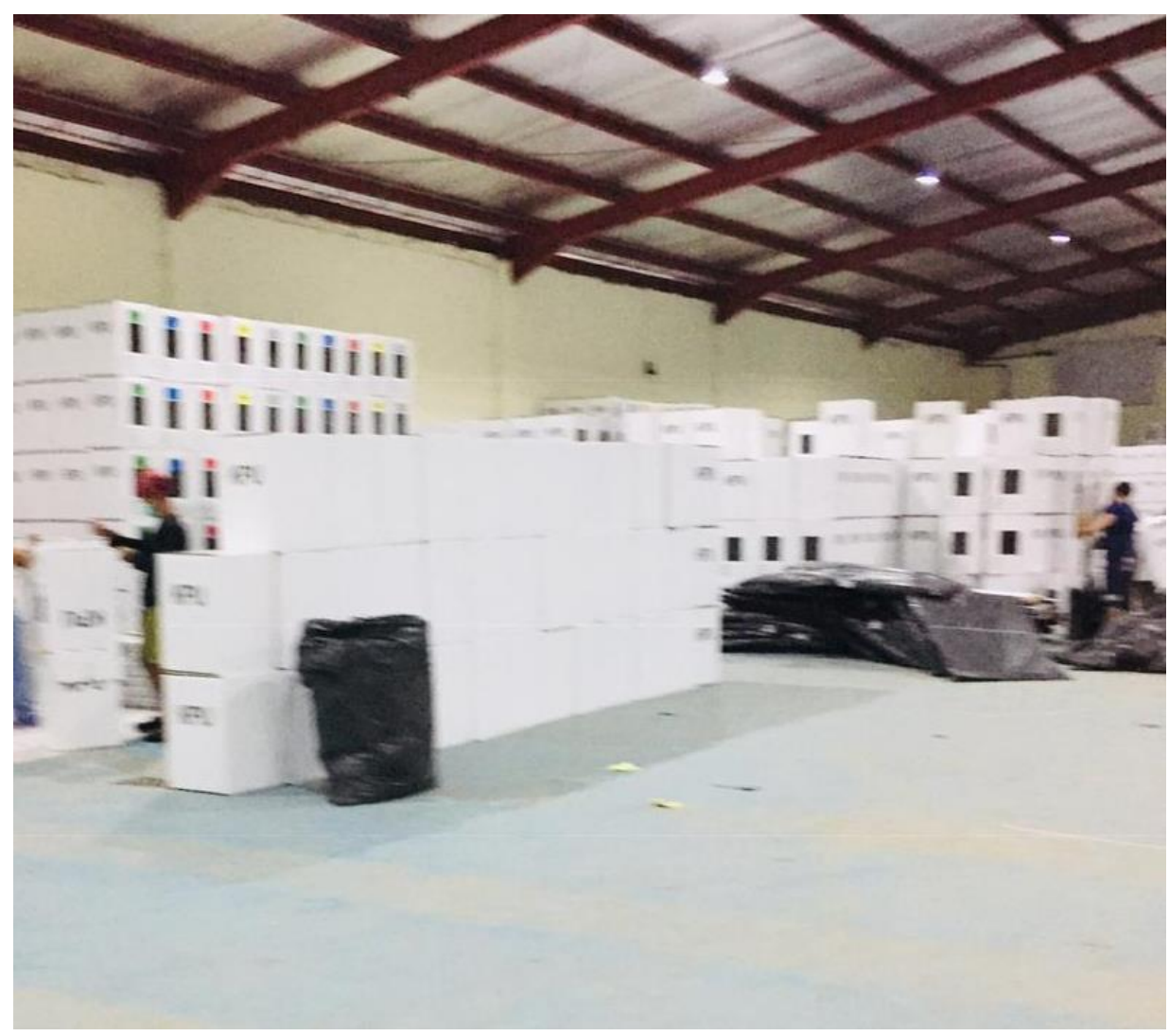

Berikut gambar area penyimpanan produk 


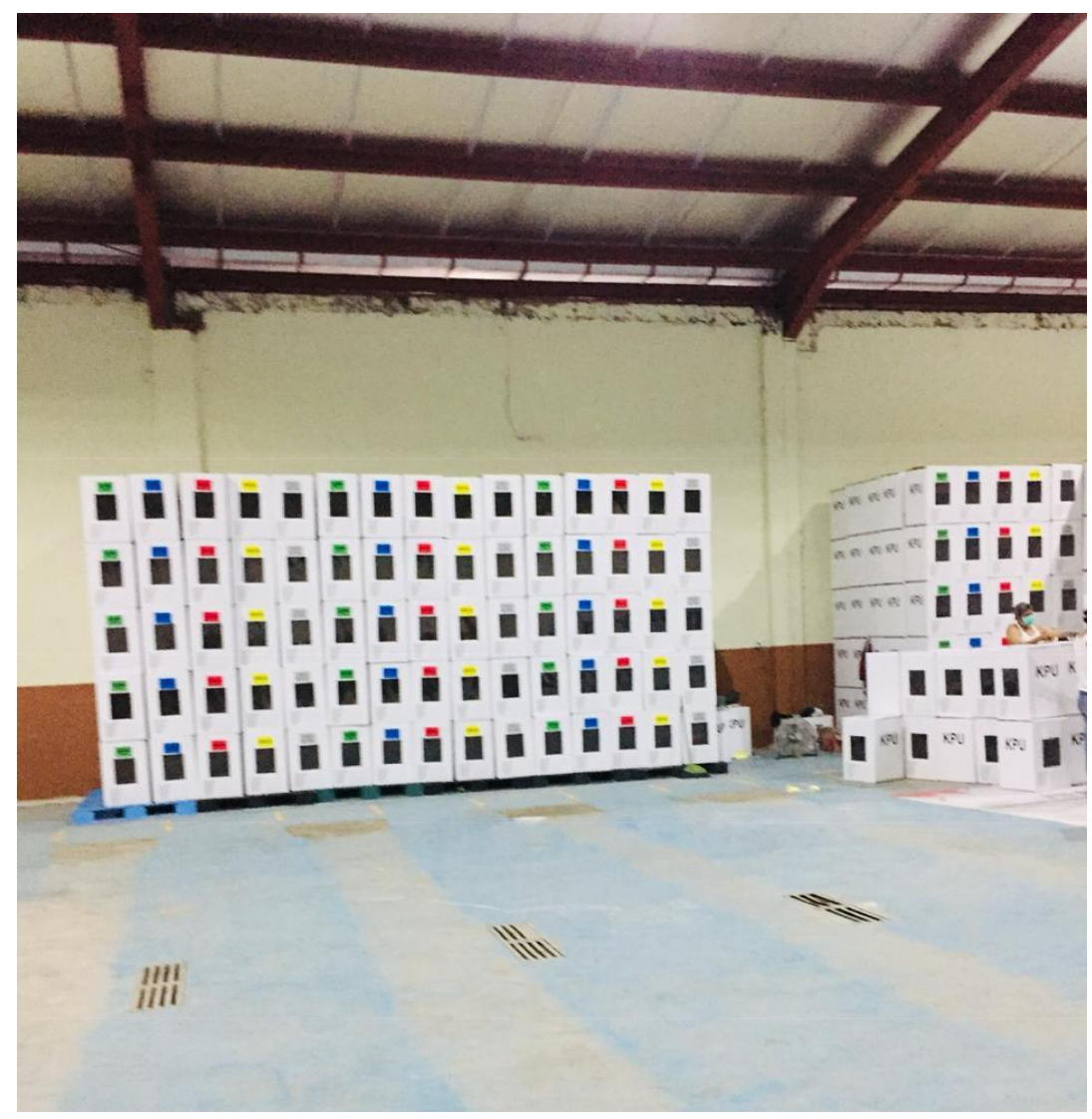

Berdasarkan hasil wawancara dengan informan dan dari studi pustaka, maka gudang logistik pemilu di KPUD Kota Depok sudah memenuhi standar minimal kriteria gudang yang baik, yaitu:

1. Lantai:

Terbuat dari beton padat dengan hardener, bersifat menahan debu dan tidak tahan terhadap tumpahan larutan bahan kimia.

2. Pencahayaan: 200 Lux (satuan kekuatan cahaya) (BPOM, 2009).

3. Kebersihan
4. Kelembaban (kelembaban relatif tidak lebih dari 60\%).

5. Suhu harus berada dalam batasan yang diterima (8-250C).

6. Bahan dan material yang disimpan tidak boleh bersentuhan langsung dengan lantai (menggunakan palet kayu dan palet plastik)

7. Jarak antar bahan mempermudah pembersihan dan inspeksi. 
Berdasarkan hasil penelitian, maka disimpulkan KPUD Kota Depok sudah memenuhi kriteria gudang yang baik sebagai gudang logistik pemilu, karena sudah memenuhi kriteria standar minimal gudang yang baik, yaitu

1. Lantai (terbuat dari beton padat dengan hardener, bersifat menahan debu dan tidak tahan terhadap tumpahan larutan bahan kimia).

2. Pencahayaan: 200 Lux (satuan kekuatan cahaya) (BPOM, 2009).

3. Kebersihan

4. Kelembaban (kelembaban relatif tidak lebih dari 60\%).

5. Suhu harus berada dalam batasan yang diterima (8-250C).

6. Bahan dan material yang disimpan tidak boleh bersentuhan langsung dengan lantai (menggunakan palet kayu dan palet plastik)

7. Jarak antar bahan mempermudah pembersihan dan inspeksi.

\section{DAFTAR PUSTAKA}

1. Assauri, S. (1993). Manajemen. Fakultas, Produksi. Lembaga Penerbit Indonesia., Ekonomi Universitas.

2. Atma, S., \& Pangkalpinang, L. (1998). PENYALURAN KOTAK DAN

\section{SURAT SUARA.}

3. Azwir, H. H., \& Patriani, O. (2017). Jurnal Optimasi Sistem Industri Perbaikan Pengelolaan Pergudangan Melalui Penerapan Sistem Informasi, 1, 10-24.

4. Barkati, Z. I. (2014). kabupaten malinau, $1-11$.

5. Fuad, A. B. B. (2014). Political Identity and Election in Indonesian Democracy: A Case Study in Karang Pandan Village - Malang, Indonesia. Procedia Environmental Sciences, 20, 477-485. https://doi.org/10.1016/j.proenv.2014.0 3.060

6. Lestari, S. B. (2015). Jurnal Ilmu Sosial. Jurnal Ilmu Sosial, 14(2), 24-41.

Retrieved from https://ejournal.undip.ac.id/index.php/il musos/article/view/10364/8241

7. Purnomo, H. (2004). Perencanaan \& Perancangan Fasilitas. Yogyakarta: Graha Ilmu.

8. Rahadian, A. ., Vikaliana, R., \& Saputra, M. (2019). Substansi Perubahan Sistem Pemilu Dan Implikasinya Berdasarkan Undang-Undang Nomor 7 Tahun 2017 Tentang Pemilihan Umum Serta RKPD Tahun 2018 Sesuai Permendagri Nomor 32 Tahun 2017 (Pendampingan Bimbingan Teknis Nasional Anggota DPRD Kota Sungai Penuh). Jurnal Komunitas Jurnal Pengabdian Masyarakat, 2(1), 32-37. Retrieved from http://ojs.stiami.ac.id/index.php/jks/arti cle/view/290

9. Rangkuti, F. (2007). Manajemen Persediaan. PT. Raja Grafindo Persada. 